Original Article

Artigo Original

Nathane Sanches Marques Silva ${ }^{1}$

Patrícia Abreu Pinheiro Crenitte ${ }^{2}$

Keywords

Language Arts Learning

Handwriting

Education

Educational Status

Descritores

Estudos de Linguagem Aprendizagem

Escrita Manual

Educação

Escolaridade

Correspondence address:

Patrícia Abreu Pinheiro Crenitte

Departamento de Fonoaudiologia da

Faculdade de Odontologia de Bauru,

Universidade de São Paulo,

Alameda Octávio Pinheiro Brisolla,

9/75, Vila Universitária, Bauru (SP),

Brazil, CEP: 17012-901.

E-mail:vp.crenitte@uol.com.br

Received: 01/02/2014

\section{Comparison of students from private and public schools on the spelling performance}

\author{
Comparação de escolares de escolas privadas e \\ públicas quanto ao desempenho ortográfico
}

\begin{abstract}
Objective: To compare the spelling ability of schoolchildren from the fourth to sixth grades of the elementary schools in the private and public schools of Bauru, São Paulo, and to verify whether errors are overcome as studies progress and the hierarchy of errors as to how often they occur. Methods: A dictation was applied to 384 schoolchildren: 206 from the private schools: 74 were at the fourth grade, 65 at the fifth grade, and 67 at the sixth grade; and 178 from the public schools; 56 at the fourth grade, 63 at the fifth grade, and 59 at the sixth grade of elementary school. Student's $t$ test was used. Results: In comparison of total spelling errors score, difference was found among the fourth and sixth grades of the private and public schools. Spelling errors decreased as education progressed, and those related to language irregularities were more common. Conclusion: Spelling ability and performance of students from the private and public schools are not similar in the fourth and sixth grades, but it is in the fifth grade. Spelling errors are gradually overcome as education progresses; however, this overcome rate was considerable between the fourth and fifth grades in the public schools. Decrease in the types of spelling errors follows a hierarchy of categories: phoneme/grapheme conversion, simple contextual rules, complex contextual rules, and language irregularities. Finally, the most common type of spelling error found was that related to language irregularities.
\end{abstract}

\section{RESUMO}

Objetivo: Comparar o perfil ortográfico dos escolares do quarto ao sexto ano do ensino fundamental de escolas privadas e públicas do município de Bauru, São Paulo, verificando se os erros são superados com o avanço na escolaridade, qual é a hierarquia de ocorrência e quais são os erros mais comuns. Métodos: Foi aplicado um ditado em 384 escolares, sendo 206 de escolas privadas, dos quais 74 eram do quarto, 65 do quinto e 67 do sexto ano; e em 178 escolares de escolas públicas, dos quais 56 eram do quarto, 63 do quinto e 59 do sexto ano do ensino fundamental. Foi aplicado o teste $t$ de Student. Resultados: Quanto à comparação do escore total de erros ortográficos, houve diferença entre o quarto e o sexto ano das escolas privadas e públicas. Ocorreu diminuição da quantidade de erros ortográficos com o avanço da escolaridade, sendo os erros ortográficos do tipo irregularidades da língua os mais comuns. Conclusão: Não são semelhantes os perfis dos erros ortográficos dos escolares de escolas privadas e públicas quanto ao quarto e ao sexto ano, sendo esse perfil semelhante no quinto ano. Os erros ortográficos são superados de forma gradativa com o avanço na escolaridade, entretanto, a superação dos erros entre o quarto e quinto ano do ensino público foi considerável. A diminuição dos tipos de erros ortográficos segue a seguinte hierarquia: categoria conversor fonema/grafema, regras contextuais simples, complexas e irregularidades da língua. Por fim, o tipo de erro mais comum é devido às irregularidades da língua.

Study carried out at the Speech Language Pathology and Audiology Department, Dental School of Bauru, Universidade de São Paulo - USP - Bauru (SP), Brazil.

(1) Graduate Program in Speech Language Pathology and Audiology, Dental School of Bauru, Universidade de São Paulo - USP - Bauru (SP), Brazil.

(2) Speech Language Pathology and Audiology Department, Dental School of Bauru, Universidade de São Paulo - USP - Bauru (SP), Brazil.

Financial support: Fundação de Amparo à Pesquisa do Estado de São Paulo - FAPESP.

Conflict of interests: nothing to declare. 


\section{INTRODUCTION}

The process of acquisition of written Portuguese is complex, as it requires the child's skills of word segmentation, identification of phoneme-grapheme correspondence, and syllabic building possibilities ${ }^{(1)}$.

The literature is contradictory when it comes to the performance of students in primary education from private and public schools. Studies have reported that the private school students have fewer spelling errors compared with public school students, but the discrepancy between school systems decreases after the fourth and fifth grades of elementary school $^{(2)}$. However, another study ${ }^{(3)}$ showed that the public schoolchildren had more spelling errors than those from the private school network, which suggested that the school system interfered in academic performance regarding spelling ability. It was also found that students at the fourth grade of the elementary school, regardless of the school system, master the grapheme-phoneme correspondence but face spelling difficulties ${ }^{(4)}$.

Spelling errors are overcome with progress in school grades, and that is why schoolchildren at the third grade of elementary school have a higher frequency of spelling errors than those at the fourth grade; therefore, as children have contact with reading and writing, such errors are overcome; so, one can say that spelling errors are part of the writing acquisition process $^{(2,5-10)}$.

In schoolchildren with no complaints of learning, the most frequent spelling errors are those of multiple representations or related to language irregularities. This type of error occurs because of contextual and morphosyntactic rules and, therefore, are common among students ${ }^{(11)}$. For schoolchildren with learning problems, spelling errors also reflect the complexity of the language, that is, they often make such errors because of the possibility of multiple representations. There are also spelling errors by omission of letters, which is a typical error that may result from phonological difficulties and less frequent among schoolchildren without complaints. Finally, errors with their basis in spoken language are also very common and show that these children have not understood yet that writing is not about literally transcribing speech. This difficulty can be overcome as the reader acquires spelling knowledge, but it is also common among children without learning complaints at the first steps of writing acquisition ${ }^{(12)}$. Thus, phonological and spelling processes are important to learn writing ${ }^{(13)}$.

Therefore, it is important to know the typical spelling development pattern of schoolchildren, so that one can identify the deviant development, both in terms of typology and the number of spelling errors.

The purpose of this study was to compare the spelling ability of students at fourth to sixth grades from private and public schools in Bauru city, São Paulo, and to identify whether spelling errors are overcome with schooling, the hierarchy of the types of spelling errors, and the most common type of errors among them.

\section{METHODS}

This study was approved by the Ethics Committee of Faculdade de Odontologia de Bauru, Universidade de São Paulo, protocol 48519/2012, and was only started after schools gave authorization and after the parents signed the informed consent.

The study was conducted in schools from private and public networks of Bauru, São Paulo. In total, 384 schoolchildren of both genders aged 9 to 11 years old participated in the research, being divided into two groups:

- Group of students from the private schools (GSPrS): composed of 206 students from three private schools of Bauru, São Paulo: 74 were at fourth grade, 65 at fifth grade, and 67 at sixth grade of elementary school. The sample of three grades was composed of students from three private schools.

- Group of students from the public schools (GSPuS): composed of 178 students from two public schools of Bauru, São Paulo: 56 were at fourth grade, 63 at fifth grade, and 59 at sixth grade of the elementary school. Children from fourth and fifth grades were from a State school, and children from sixth grade were from another one of Bauru, São Paulo.

To be included in this study, the schoolchildren should be enrolled in the selected schools, in fourth to sixth year of elementary school, and have the informed consent form signed by their parents/caregivers.

Exclusion criteria were incomplete spelling task, presence of sensory or mental disorders, diagnosis of learning disorders, or complaints and manifestations observed by their teachers.

To assess spelling in both the groups, a balanced dictation ${ }^{(14)}$ consisting of 50 words was applied collectively within the school environment. All spelling testing was applied by the researcher at the beginning of 2012 second semester.

Dictations were assessed according to a protocol proposed by the author ${ }^{(14)}$, and spelling errors were divided and classified as total errors score (TES), phoneme/grapheme conversion category (PGC), simple contextual rules category (SCR), complex contextual rules category (CCR), and language irregularities category (LI), to achieve a mean score of errors per grade and category.

Category of PGC refers to incorrect choice of grapheme to represent a sound, as when voiceless sounds are changed by voiced sounds or when there are replacements, omissions, additions, transpositions, or inversions. In category $\mathrm{SCR}$, we placed errors related to rules defining the value of the grapheme in the context. Category of CCR held word stresses features, and category of LI was composed of multiple representations ${ }^{(14)}$.

The program Statistica, version 5.1 (Stat Soft, Inc., Tulsa, USA), was used to analyze all results. Data were analyzed descriptively and statistically by mean and standard deviation. Data were also submitted to inferential statistical analysis with Student's $t$-test to compare the spelling ability between students from the private and public schools, in addition to the decrease in total score of spelling errors and types of errors per school year. Significance level of 5\% $(\mathrm{p}<0.05)$ was adopted. 


\section{RESULTS}

The sample was composed of 384 students of both the genders, aged 9-11 years, enrolled in the fourth to sixth grades of the elementary school. GSPrS held 206 schoolchildren from three private schools, of which 74 were at the fourth grade, 65 at the fifth grade, and 67 at the sixth grade, being the sample of all grades composed by students from the private schools. GSPuS held 178 schoolchildren from two public schools, of which 56 were at the fourth grade, 63 at the fifth grade, and 59 at the sixth grade of the elementary schools; however, students at the fourth and fifth grades were from a State school and students at the sixth grade, from another one of Bauru, São Paulo.

We found differences when comparing schoolchildren at the fourth year of GSPrS and GSPuS regarding TES and other categories analyzed, which shows that students from GSPuS had a worse performance compared with students of GSPrS, as shown in Table 1. This was not seen when comparing the school's fifth grade of GSPrS and GSPuS; however, when comparing the school's sixth grade, there were differences for TES and for categories PGC and LI. This shows that schoolchildren of GSPuS had an inferior performance in spelling in categories PGC and LI compared with the students of GSPrS.

It was also found that, as education progresses, the number of TES decreased in both groups, except for the fifth grade of GSPuS, whose children made less spelling errors than those of the sixth grade in the same group. However, there were

Table 1. Comparison between the mean and standard deviation of spelling errors of schoolchildren from both the groups

\begin{tabular}{cccccc}
\hline \multirow{2}{*}{ Year } & \multicolumn{2}{c}{$\begin{array}{c}\text { Students from } \\
\text { private schools }\end{array}$} & \multicolumn{2}{c}{$\begin{array}{c}\text { Students from } \\
\text { public schools }\end{array}$} & p-value \\
\cline { 2 - 4 } & Mean & SD & Mean & SD & \\
\hline Fourth & & & & & \\
TES & 19.33 & 15.05 & 36.04 & 12.76 & $0.0000^{*}$ \\
PGC & 2.38 & 3.36 & 5.13 & 5.07 & $0.0003^{*}$ \\
SCR & 2.08 & 2.64 & 6.45 & 2.68 & $0.0000^{*}$ \\
CCR & 5.15 & 2.97 & 8.2 & 1.17 & $0.0000^{*}$ \\
LI & 9.71 & 8.28 & 16.27 & 6.78 & $0.0000^{*}$ \\
Fifth & & & & & \\
TES & 15.19 & 9.15 & 15.8 & 11.56 & 0.7408 \\
PGC & 1 & 1.39 & 1.5 & 2.29 & 0.1365 \\
SCR & 1.45 & 1.67 & 1.9 & 3.17 & 0.3148 \\
CCR & 5.41 & 3.12 & 4.8 & 2.77 & 0.2448 \\
LI & 7.33 & 4.91 & 7.55 & 6.3 & 0.8256 \\
Sixth & & & & & \\
TES & 15.51 & 10.01 & 20.04 & 10.25 & $0.0135^{*}$ \\
PGC & 1.31 & 1.7 & 2.02 & 2.3 & $0.0493^{*}$ \\
SCR & 1.67 & 1.77 & 2.23 & 2.15 & 0.1115 \\
CCR & 5.67 & 2.88 & 6.55 & 2.46 & 0.0695 \\
LI & 6.85 & 5.82 & 9.25 & 5.83 & $0.0227^{*}$ \\
\hline
\end{tabular}

*Significant values $(p<0.05)$, arithmetic mean test, standard deviation, and Student's $t$-test.

Caption: SD = standard deviation; TES = total errors score; $P G C=$ phoneme/ grapheme conversion; $\mathrm{SCR}=$ simple contextual rules; $\mathrm{CCR}=$ complex contextual rules; $\mathrm{LI}=$ language irregularities only differences in mean TES as education progresses according to the comparison between the fourth and fifth grades of GSPuS (Table 2).

When each category of spelling error was analyzed, it is seen that in both private and public schools, there was a decrease in errors from the four categories analyzed as education progresses (Tables 3 to 6). For categories PGC and LI, we found differences between fourth and fifth grades of both groups. For category SCR, difference was only found between the fourth and fifth grades of GSPuS. Finally, for category CCR, difference was found between fourth and fifth grades when it comes to decrease of errors among the students of GSPuS; difference was also found between the sixth grade of GSPuS but owing to increase in errors.

Note that the average number of spelling errors is similar in both GSPrS and GSPuS, as there were less spelling errors

Table 2. Differences between the mean and standard deviation of total errors score according to grade in both the groups

\begin{tabular}{|c|c|c|c|c|c|}
\hline & Mean & SD & Mean & SD & $\mathrm{p}$-value \\
\hline \multicolumn{6}{|c|}{ Students from private schools } \\
\hline Fourth $x$ Fifth & 19.33 & 15.05 & 15.19 & 9.15 & 0.0561 \\
\hline Fifth $x$ Sixth & 15.19 & 9.15 & 15.51 & 10.01 & 0.8484 \\
\hline \multicolumn{6}{|c|}{ Students from public schools } \\
\hline Fourth $x$ Fifth & 36.04 & 12.76 & 15.8 & 11.56 & $0.0000^{*}$ \\
\hline Fifth $x$ Sixth & 15.8 & 11.56 & 20.04 & 10.25 & $0.0345^{*}$ \\
\hline
\end{tabular}

${ }^{*}$ Significant values $(p<0.05)$, arithmetic mean test, standard deviation, and Student's $t$-test.

Caption: $\mathrm{SD}=$ standard deviation

Table 3. Differences between the mean and standard deviation of the category phoneme/grapheme conversion according to grade in both the groups

\begin{tabular}{|c|c|c|c|c|c|}
\hline & Mean & SD & Mean & SD & $\mathrm{p}$-value \\
\hline \multicolumn{6}{|c|}{ Students from private schools } \\
\hline Fourth $x$ Fifth & 2.38 & 3.36 & 1 & 1.39 & $0.0025^{*}$ \\
\hline Fifth $x$ Sixth & 1 & 1.39 & 1.31 & 1.7 & 0.2543 \\
\hline \multicolumn{6}{|c|}{ Students from public schools } \\
\hline Fourth $x$ Fifth & 5.13 & 5.07 & 1.5 & 2.29 & $0.0000^{*}$ \\
\hline Fifth $x$ Sixth & 1.5 & 2.29 & 2.02 & 2.3 & 0.2135 \\
\hline
\end{tabular}

${ }^{*}$ Significant values $(p<0.05)$, arithmetic mean test, standard deviation, and Student's $t$ test.

Caption: $\mathrm{SD}=$ standard deviation

Table 4. Differences between the mean and standard deviation of the category simple contextual rules according to grade in both the groups

\begin{tabular}{|c|c|c|c|c|c|}
\hline & Mean & SD & Mean & SD & $\mathrm{p}$-value \\
\hline \multicolumn{6}{|c|}{ Students from private schools } \\
\hline Fourth $x$ Fifth & 2.08 & 2.64 & 1.45 & 1.67 & 0.1003 \\
\hline Fifth $x$ Sixth & 1.45 & 1.67 & 1.31 & 1.7 & 0.4662 \\
\hline \multicolumn{6}{|c|}{ Students from public schools } \\
\hline Fourth $x$ Fifth & 6.45 & 2.68 & 1.9 & 3.17 & $0.0000^{*}$ \\
\hline Fifth $x$ Sixth & 1.9 & 3.17 & 2.23 & 2.15 & 0.5051 \\
\hline
\end{tabular}

${ }^{*}$ Significant values $(p<0.05)$, arithmetic mean test, standard deviation, and Student's $t$ test.

Caption: $\mathrm{SD}=$ standard deviation 
of category PGC, followed by SCR, and CCR and LI, except for the fourth grade of GSPrS, in which the descending order of errors was in categories SCR, PGC, CCR, and LI. Errors related to LI were the most common ones among schoolchildren in GSPrS and GSPuS, at all grades (Table 7).

Table 5. Differences between the mean and standard deviation of the category complex contextual rules according to grade in both the groups

\begin{tabular}{|c|c|c|c|c|c|}
\hline & Mean & SD & Mean & SD & $p$-value \\
\hline \multicolumn{6}{|c|}{ Students from private schools } \\
\hline Fourth x Fifth & 5.15 & 2.97 & 5.41 & 3.12 & 0.6158 \\
\hline Fifth $x$ Sixth & 5.41 & 3.12 & 5.67 & 2.88 & 0.6195 \\
\hline \multicolumn{6}{|c|}{ Students from public schools } \\
\hline Fourth $x$ Fifth & 8.2 & 1.17 & 4.8 & 2.77 & $0.0000^{*}$ \\
\hline Fifth $x$ Sixth & 4.8 & 2.77 & 6.55 & 2.46 & $0.0004^{*}$ \\
\hline
\end{tabular}

*Significant values $(p<0.05)$, arithmetic mean test, standard deviation, and Student's $t$-test.

Caption: $\mathrm{SD}=$ standard deviation

Table 6. Differences between the mean and standard deviation of the category language irregularities according to grade in both the groups

\begin{tabular}{|c|c|c|c|c|c|}
\hline & Mean & SD & Mean & SD & $\mathrm{p}$-value \\
\hline \multicolumn{6}{|c|}{ Students from private schools } \\
\hline Fourth $x$ Fifth & 9.71 & 8.28 & 7.33 & 4.91 & $0.0448^{*}$ \\
\hline Fifth $x$ Sixth & 7.33 & 4.91 & 6.85 & 5.82 & 0.6099 \\
\hline \multicolumn{6}{|c|}{ Students from public schools } \\
\hline Fourth $x$ Fifth & 16.27 & 6.78 & 7.55 & 6.3 & $0.0000^{*}$ \\
\hline Fifth $x$ Sixth & 7.55 & 6.3 & 9.25 & 5.83 & 0.1252 \\
\hline
\end{tabular}

*Significant values $(p<0.05)$, arithmetic mean test, standard deviation, and Student's $t$-test.

Caption: $\mathrm{SD}=$ standard deviation

Table 7. Hierarchy of decrease of types of spelling errors according to progress in education among the students from both the groups

\begin{tabular}{cccccc}
\hline \multirow{2}{*}{ Grade } & \multicolumn{3}{c}{\begin{tabular}{c} 
Students from \\
\multicolumn{2}{c}{ Students from } \\
\end{tabular}} & \multicolumn{3}{c}{ private schools } & \multicolumn{2}{c}{ public schools } \\
\cline { 2 - 6 } & Mean & SD & Variable & Mean & SD \\
\hline Fourth & & & & & \\
SCR & 2.08 & 2.64 & PGC & 5.13 & 5.07 \\
PGC & 2.38 & 3.36 & SCR & 6.45 & 2.68 \\
CCR & 5.15 & 2.97 & CCR & 8.2 & 1.17 \\
LI & 9.71 & 8.28 & LI & 16.27 & 6.78 \\
Fifth & & & & & \\
PGC & 1 & 1.39 & PGC & 1.5 & 2.29 \\
SCR & 1.45 & 1.67 & SCR & 1.9 & 3.17 \\
CCR & 5.41 & 3.12 & CCR & 4.8 & 2.77 \\
LI & 7.33 & 4.91 & LI & 7.55 & 6.3 \\
Sixth & & & & & \\
PGC & 1.31 & 1.7 & PGC & 2.02 & 2.3 \\
SCR & 1.67 & 1.77 & SCR & 2.23 & 2.15 \\
CCR & 5.67 & 2.88 & CCR & 6.55 & 2.46 \\
LI & 6.85 & 5.82 & LI & 9.25 & 5.83 \\
\hline
\end{tabular}

Caption: $\mathrm{SD}=$ standard deviation; $\mathrm{TES}=$ total errors score; $\mathrm{PGC}=$ phoneme/ grapheme conversion; $\mathrm{SCR}=$ simple contextual rules; $\mathrm{CCR}=$ complex contextual rules; LI = language irregularities

\section{DISCUSSION}

Ávila et al. ${ }^{(15)}$ have reported that regardless of the school network, spelling is learned as students progress in grades. In public schools, spelling is also improved as education progresses $^{(2)}$. The results of this study refute some research findings that suggest the school network, that is, public or private systems, as a factor interfering with academic performance as to spelling ability ${ }^{(3)}$, once there was no difference in mean of spelling errors among students at the fifth grade in GSPrS and GSPuS. Another study reported that schoolchildren at the fourth grade of private schools had less difficulty in writing compared with the students from public schools ${ }^{(16)}$, in agreement with our data when it comes to fourth grades in GSPrS and GSPuS.

Berberian et al. have reported that the acquisition of spelling is a continuous process ${ }^{(8)}$ that is learned from the contact with written language. Therefore, as students progress in school grades, there is a gradual reduction of spelling errors, indicating that education progress leads students to master spelling rules ${ }^{(2,5-10,15,17)}$.

In a study conducted with Greek schoolchildren ${ }^{(18)}$ of the third, fourth, and seventh grades, it was found that students in the higher grades made fewer spelling errors in spelling tasks, which also happens in Brazilian schoolchildren. Similarly, a study conducted with students who spoke German, which analyzed spelling errors in spontaneous writing in four levels of education of the German primary school, showed a significant reduction of errors as they progressed in grades ${ }^{(19)}$.

Authors from Portugal studied spelling compared with writing with 72 schoolchildren at the fourth grade and 78 at the sixth grade and concluded that there was no difference between the number of spelling errors in both grades studied, which, according to them, contradicts that it would be logical or expected that students at the sixth grade make fewer errors compared with those at the fourth grade ${ }^{(20)}$.

Therefore, students make more errors when they are at the initial phases of spelling learning compared with the later phases $^{(13)}$. So, we found a positive effect of educational progress in improvement of spelling errors among students from the private network in our sample, as error occurrences decreased. This contradicts another study ${ }^{(13)}$, which reported significant differences in decrease of spelling errors among students from the private network.

However, statistical difference was found between the fourth and fifth grades of the public school system. Capellini, Butarelli and Germano ${ }^{(17)}$ have also found that the decrease in types of spelling errors among the schoolchildren of the public system is significant.

However, in the sixth grade of public system schools, there was an increase in the number of spelling errors related to the previous school year. The increasing in number of spelling errors may be due to heterogeneity that may occur within the school network $^{(21)}$, as the sixth grade sample was composed of students from a State school and the fourth and fifth grades, students from another State school of the public network in the city of Bauru, São Paulo.

Decrease in spelling errors among schoolchildren was also related to the type of error made. This has also been reported 
by other authors who found that both frequency and type of spelling errors decrease as school years go by, in both the educational systems, and that this decrease may be considered a mark of spelling learning ${ }^{(13)}$.

Errors as results of elaborations and reelaborations performed by the schoolchild during the learning process; so, they change and decrease according to the phases of literacy ${ }^{(5)}$. Spelling errors decrease as they progress in school grades, which show that their knowledge about spelling rules increases. Not only the TES decreases but also the spelling errors become less frequency as to type.

We observed a hierarchy in spelling learning, marked by the decrease in the occurrence of certain types of errors, once both GSPrS and GSPuS had less spelling errors in categories PGC, SCR, CCR, and LI (Table 7). Another study has also found a hierarchy in spelling rules learning, as some contexts are used more properly than others; also in addition, as children grow and education progresses, they start using spelling rules more consistently ${ }^{(22)}$.

This hierarchy was not followed only by schoolchildren at the fourth grade in private schools who presented higher mean values for category PGC compared with SCR (Table 7), but it can also be explained by the fact that these children were at the initial phase of literacy process, which show that errors in category PGC is related to spoken language used as a support in writing, and the more the child uses the oral language as a basis to write, the more they make nonconventional spelling ${ }^{(6)}$. As they get in contact with writing, these errors still happen but in lower proportions.

In the fifth and sixth grades of elementary school, there was a high incidence of spelling errors in both groups involving category LI, which is characterized by multiple representations. Other studies also found greater occurrence of errors related to multiple representations ${ }^{(23)}$.

This type of error was shown to be more common in writing, once they require more complex knowledge and once contextual and morphosyntactic rules are needed ${ }^{(11)}$. The student must replace the alphabetical hypothesis by the spelling hypothesis to write correctly, as spelling mastering presupposes that words are not to be written based on spoken language ${ }^{(24)}$.

German native speakers in this age were also found to face difficulties when a phoneme is represented by different graphemes or when a grapheme represents different phonemes ${ }^{(19)}$. Similarly, schoolchildren from Portugal in the fourth and sixth grades made spelling errors related to multiple representations, but other types of errors are more common in writing among them. Spelling errors related to multiple representations ranked fourth among the most frequent ones, behind only accentuation, vowel replacement, and letters omission ${ }^{(20)}$.

Thus, it is suggested that, when evaluating the spelling of a schoolchild, within the clinic or school scenario, one should take into account the most common spelling errors in writing. One should also check that the most frequent type of error in writing of students is also the most frequent among children with typical development. Although these results are promising, the small sample was a limiting factor, but this was because of the lack of adherence to the study by schoolchildren from both the private and public schools.

\section{CONCLUSION}

The pattern of spelling errors among students from the fourth to sixth grades in private and public schools of Bauru, São Paulo, is not similar when the fourth and sixth grades of elementary school are compared, but this similarity is evident in the fifth grade when comparing private and public schools. Spelling errors are overcome gradually as education progresses; however, it is significant when the fourth and fifth grades of the public school system are compared. A hierarchy in the occurrence of spelling errors in all grades and both school systems was observed, except in the fourth year of the private network, as errors, in ascending order, were less frequent in writing of students from category PGC, followed by SCR, CCR, and LI. Finally, the spelling errors related to language of irregularities are the most common in all grades and both in the private and public schools.

\section{ACKNOWLEDGMENTS}

We thank Fundação de Amparo à Pesquisa do Estado de São Paulo (FAPESP) for supporting this research, with protocol number 2011/23831-0. We also thank the schools, coordinators, teachers, parents, and schoolchildren who participated in this study.

*NSMS performed study and schedule design, data collection and analysis, writing of the paper, and paper submission processes; PAPC was the advisor professor and participated in the study and schedule design, data analysis, revision of the paper, and its final version.

\section{REFERENCES}

1. Santos MJ, Alves PS. Padrão Ortográfico: um estudo com crianças do $4^{\mathrm{o}}$ ano do ensino fundamental. In: Anais dos Simpósios da Pedagogia da Universidade Federal de Goiás. Catalão; 2010 p. 279-90.

2. Zanella MS. Ortografia no ensino fundamental: um estudo sobre as dificuldades no processo de aprendizagem da escrita. Poíesis Pedagógica. 2010;8(2):109-25.

3. Bigarelli JFP, Ávila CRB. Habilidades ortográficas e de narrativa escrita no ensino fundamental: características e correlações. J Soc Bras Fonoaudiol. 2011;23(3):237-47.

4. Santos MTM, Befi-Lopes DM. Análise da ortografia de alunos do $4^{\circ}$ ano do Ensino Fundamental a partir de ditado de palavras. CoDAS. 2013;25(3):256-61.

5. Zuanetti PA, Corrêa-Schnek AP, Manfredi AKS. Comparação dos erros ortográficos de alunos com desempenho inferior em escrita e alunos com desempenho médio nesta habilidade. Rev Soc Bras Fonoaudiol. 2008;13(3):240-5.

6. Queiroga BAM, Lins MB, Pereira MALV. Conhecimento morfossintático e ortografia em crianças do ensino fundamental. Psic Teor e Pesq. 2006;22(1):95-9.

7. Mota MMPE, Silva KCA. Consciência morfológica e desenvolvimento ortográfico: um estudo exploratório. Psicol Pesq. 2007;1(2):86-92.

8. Berberian AP, Massi GA, Santana APO, Guarinello AC, Machado MLCA, Bortolozzi KB, et al. Análise de ocorrências ortográficas não convencionais produzidas por alunos do Ensino Fundamental. Tuiuti: Ciência e Cultura. 2008;39:23-39. 
9. Barbosa PMF, Bernardes NGB, Misorelli MI, Chiappetta ALML. Relação da memória visual com o desempenho ortográfico de crianças de $2^{\mathrm{a}}$ e $3^{\mathrm{a}}$ séries do ensino fundamental. Rev CEFAC. 2010;12(4):598-607.

10. Batista AO, Capellini SA. Desempenho ortográfico de escolares do $2^{\circ}$ ao $5^{\circ}$ ano do ensino privado do município de Londrina. Psicol Argum. 2011;29(67):411-25.

11. Rosa CC, Gomes E, Pedroso FS. Aquisição do sistema ortográfico: desempenho na expressão escrita e classificação dos erros ortográficos. Rev CEFAC. 2012;14(1):39-45.

12. Zorzi JL, Ciasca SM. Caracterização dos erros ortográficos em crianças com transtornos de aprendizagem. Rev CEFAC. 2008;10(3):321-31.

13. Capellini SA, Amaral AC, Oliveira AB, Sampaio MN, Fusco N, CerveraMérida JF, et al. Desempenho ortográfico de escolares do $2^{\circ}$ ao $5^{\circ}$ ano do ensino público. J Soc Bras Fonoaudiol. 2011;23(3):227-36.

14. Moojen SMP. A escrita ortográfica na escola e na clínica: teoria, avaliação e tratamento. São Paulo: Casa do Psicólogo; 2009.

15. Ávila CRB, Kida ASB, Carvalho CAF, Paolucci JF. Tipologia de erros de leitura de escolares brasileiros considerados bons leitores. Pró-Fono R Atual Cient. 2009;21(4):320-5.

16. Joly MCRA, Barros DP, Marini JAS. Dificuldades ortográficas na escrita no ensino fundamental. Interação Psicol. 2009;13(2):275-85.

17. Capellini SA, Butarelli APKJ, Germano GD. Dificuldades de aprendizagem da escrita em escolares de $1^{\mathrm{a}}$ a $4^{\mathrm{a}}$ séries do ensino público. Rev Educ Quest. 2010;37(23):146-64.
18. Protopapas A, Fakou A, Drakopoulou S, Skaloumbakas C, Mouzaki A. What do spelling errors tell us? Classification and analysis of errors made by Greek schoolchildren with and without dyslexia. Read Writ. 2013;26(5):615-46.

19. Berkling K, Fay J, Stüker S. Speech technology-based framework for quantitative analysis of German spelling errors in freely composed children's texts. In: The International Speech Communication Association Special Interest Group on Speech and Language Technology in Education (SLaTE). Venice; 2011. p. 65-8.

20. Moura IS. Ortografia e produção textual em diferentes níveis do ensino básico [dissertação]. Aveiro: Universidade de Aveiro; 2012.

21. Menezes-Filho NA. Os determinantes do desempenho escolar do Brasil. In: Duarte PG, Silber S, Guilhoto J. O Brasil do século XXI. Saraiva: São Paulo; 2011. p. 231-56.

22. Meireles ES, Correa J. Regras contextuais e morfossintáticas na aquisição da ortografia da língua portuguesa por criança. Psic Teor e Pesq. 2005;21(1):77-84.

23. Casemiro JR, Ribeiro KB, Matta TRG, Soares AJC, Cárnio MS Interferências de estímulos visuais na produção escrita de escolares ouvintes sem queixas de alterações na escrita. Rev Soc Bras Fonoaudiol. 2011;16(4):396-404.

24. Romanelli BMB, Guimarães SRK. Ortografia do português do Brasil e habilidades linguísticas em crianças bilíngues francês-português. Psicol Pesq. 2009;3(1):101-14. 